\title{
Anti-AMHR2 Monoclonal Antibody GM102
}

National Cancer Institute

\section{Source}

National Cancer Institute. Anti-AMHR2 Monoclonal Antibody GM102. NCI Thesaurus.

Code $\mathrm{C136985.}$

An eng ineered, humanized, low fucose monoclonal antibody ag ainst mullerian hormone receptor II (Müllerian Inhibiting Substance Receptor II; AMHR2; AMHRII), with potential antineoplastic activity. Upon administration, anti-AMHR2 monoclonal antibody GM102 targets, binds to and inhibits AMHR2 and its downstream signaling pathways. GM102 primarily induces antibody dependent cellular cytotoxicity (ADCC) directed against AMHR2-expressing tumor cells through binding to CD16 (Fc-gammaRIIIa) that is present on immune effector cells. Decreased antibody fucosylation increases its affinity for binding to CD16 and ultimately enhances ADCC. AMHR2 is expressed in a subset of gynecological cancers. 